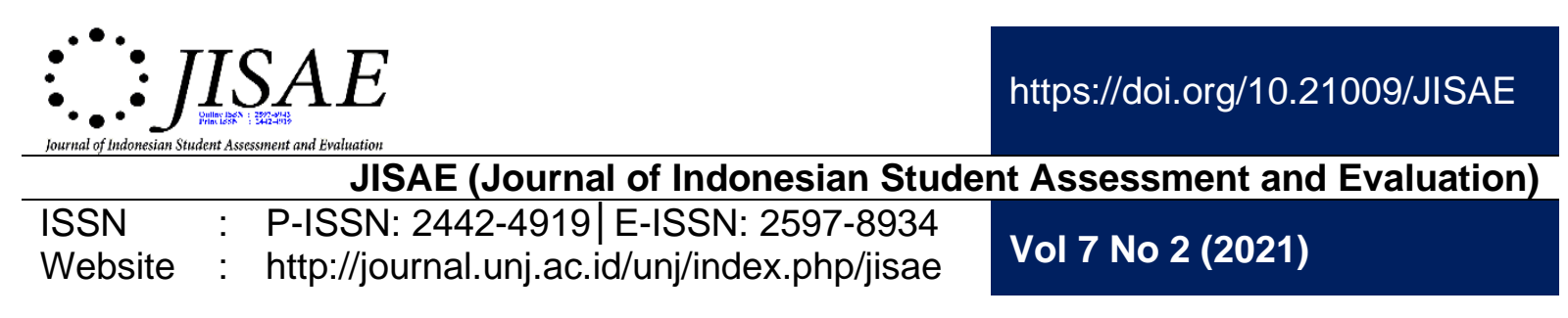

\title{
ONLINE LEARNING EVALUATION OF PAI CLASS 5 STUDENTS MIN 1 LANGSA
}

\begin{abstract}
Siti Rahma
Pascasarjana Pendidikan Agama Islam (PAI) IAIN Langsa, Aceh
\end{abstract}

\section{ABSTRACT}

Education is the process of changing the attitude and behavior of a person or group for the better through teaching / guidance and training. In the process, the teacher plays an important role in the delivery of material so that it has an influence on the success of their students. The subject learning of PAI (Islamic education) at MIN 1 Langsa is currently less effective and efficient due to the Covid-19 pandemic (corona virus disease) which makes teachers and students unable to meet face to face directly. Students asked to learn from home using online media. Online learning is undirect face-to-face learning between teachers and students by accessing internet networks and using social media to interact or exchange information. This study aims to describe the online learning of Islamic Education lessons at MIN 1 Langsa. The research approach is descriptive qualitative using primary and secondary data sources. The data collection uses the method of observation, documentation and interviews. The analysis of data using reduction, display data and conclusion. The result of the research showed that online learning PAl lessons carried out at MIN 1 Langsa used the Whatsapp application. Students at home are accompanied by their parents in studying the material and exercises provided by their teachers through the Whatsapp application. Because learning is done online, teachers must be more thorough and focused in evaluating learning activities. Students also complained that they had difficulties with poor internet networks. Some of them also do not have cell phones based on Android and some are not proficient in using them, it is making the learning process ineffective.

Keywords: Learning, Online, Students

\section{INTRODUCTION}

The notion of education is defined as conscious and deliberate and full of responsibility activities carried out by people so as to create mature interactions in the desired direction and continuously (Abu Ahmad \& Nur Uhbiyaty 2007). Education is expected to provide changes for the nation for the better. Education is closely related to learning. Learning is defined as a process of interaction between educators and students with learning resources in one learning environment (Law No. 20 of 2003). 
Religious education is a compulsory subject that must be followed by students at school, both at the elementary, junior high, high school and university levels. This is stated in the National Education System Law No. 20 of 2003, "every student has the right to receive religious education in accordance with his / her religion and it taught by religious educators" (Sidiknas, 2010)

From year to year in Indonesia and other parts of the world learning is carried out face to face in the same place. Since the pandemic entered the territory of this country, learning in Indonesia has not been disturbed. Reporting from the kompas.com page, the Indonesian government announced 2 cases of positive Covid-19 patients in Indonesia on March 2, 2020. The closure of the school was simultaneously carried out on March 16, 2020 following the decision of Minister of Education and Culture Nadiem Makarim to cancel the National Examination and ask schools to implement home learning or distance learning. Far through circular letter no 4 of 2020 on March 24, 2020 (CNN.Com)

Distance learning or online learning is a learning system using tools that support pedagogy (educational aids), which are made possible through the internet and network-based technology to facilitate learning and knowledge through action and meaningful interactions (Novita Amesi and Abdul Hamid K, 2015). The drastic change in learning methods overwhelmed teachers, parents and students. This is not unreasonable, among the most common problems are network limitations and not all students and teachers have devices not to mention that the internet is not evenly distributed in all regions. Likewise, learning Islamic education at MIN 1 Langsa is carried out online. This implementation for the first time is protected for both teachers and students. Regarding various kinds of problems related to students and teachers in online learning, the author is interested in knowing what are the obstacles and conveniences faced by teachers and students while using this distance learning.

\section{METHOD}

This study uses a qualitative approach, research that intends to understand the phenomena experienced by research subjects such as behavior, perception, motivation, action and others (Lexy J Moleong, 2009). This type of research is a descriptive field research. In this study the authors sought and collected information and data relating to the subject and object of research which contained the study of the ease and constraints analysis in online learning Islamic Education lessons at MIN 1 Langsa. The data collection uses the method of observation, documentation and interviews.

Data sources were obtained from primary data and secondary. Primary data is data obtained directly from research subjects using measurement tools. The direct subjects are teachers and students of grade V at MIN 1 Langsa. Secondary data is obtained from other parties in the form of available documents or reports. Data analysis used reduction, data display and conclusions. The data validity assurance techniques using triangulation techniques and triangulation of sources. Source triangulation is getting data from different sources with the same technique while technical triangulation is getting data from the same source with different techniques (Sugiyono, 2011) 


\section{RESULT AND DISCUSSION}

The research was conducted at MIN 1 Langsa with the research subject being a civil servant teacher who teaches Islamic studies in class V. Class V consists of 5 classes with 160 students. Based on the results of interviews with the teacher and students, it was found that online learning was carried out in two meetings a week. Learning is carried out using the WhatsApp application. In one meeting there are one to two learning materials. The lesson given must have an element of environmental love. Learning is carried out starting at 07:00 WIB. The teacher explains the material related to the material to be given. After explaining the material, the teacher asked them what they did not understand. If there are no students who ask questions, the teacher gives an assignment to do then it is photographed and sent to the Whastsapp group at 12:00 WIB. Students also have to submit their assignments to school once a week. Students are assisted by their parents at home in doing the assignments given by the teacher and sometimes search for answers on google. Many parents complain of difficulties in teaching their children at home if there are materials that have not been mastered.

From the explanation above, it can be seen that online learning has gone well. The teacher explains the material on the group WhatsApp, then the students ask what they don't understand. Furthermore, the teacher provides exercises to determine the extent to which students understand the material being taught. Collect assignments on time by photographing the assignment sheets they have worked on and collecting them once a week to school. The convenience that can be obtained from this online learning is that students do not need to come to the school, of course it saves time, effort and money. In addition, students are also assisted by their parents to learn at home, parents can control the development of their own children. For teachers, the benefits obtained from online learning are being able to know directly the learning outcomes of the students.

The obstacles faced in online learning are that teachers must be more focused and careful in examining student assignments that are sent individually in one day to two lessons. In addition, students also find it difficult to understand the material presented by the teacher through online media and the teacher also cannot explain the material optimally. Students also complained about the poor network that interfered with learning activities. The parents' lack of understanding of the material provided is also an obstacle for students in understanding learning.

\section{CONCLUSSION}

Based on the results of the study, it can be concluded that online learning is learning without face to face directly between teachers and students, but is carried out online, assisted by an androd mobile phone by downloading the WhatsApp application, then creating a learning group and connecting to the internet network to exchange information and interaction. The learning process starts at 007: 00 WIB with the teacher explaining the learning material until the students understand then giving assignments and answers are sent no later than 12:00 WIB via private chat. In a day of learning up to two times and must include the element of environmental love in the material presented.

The ease of online learning is that learning outcomes can be known directly, learning activities are not limited to distance and time. In addition, parents can control their children at home. The obstacles are, the teacher must be extra careful in checking the student answer sheets that are sent personally, the poor internet network makes the learning process disrupted. 


\section{REFERENCE}

H. Abu Ahmad dan Nur Uhbiyati, IImu Pendidikan, Jakarta: PT. Rineka Cipta, 2007

Novita Amesi dan Abdul Hamid K, Penggunaan Media Belaar Online-offline dan Komunikasi Interpersonal terhadap Hasil Belajar Bahasa Inggris dalam Jurnal Teknologi dan Informasi \&Komunikasi dalam Pendidikan, vol 2 no 1, Juni 2015, J.Moleong, Lexy, Metodologi Penelitian Kualitatif, (Bandung: Rosdakarya, 2009 Undang-Undang No. 20 Tahun 2003 Tentang Sistem Pendidikan Nasional PERMENDIKBUD No. 4 Tahun 2020 Tentang Pelaksanaan Kebijakan Pendidikan Dalam Masa Darurat Penyebaran Covid-19

Sugiyono, Metode Penelitian Pendidikan Kualitatif, Kuantitatif, $R$ \& $D$. Bandung: Alfabeta, 2011 